\title{
KAITAN ANTARA PREVALENSI GIZI BURUK DENGAN PDRB PER KAPITA DAN TINGKAT KEMISKINAN SERTA ESTIMASI KERUGIAN EKONOMI AKIBAT GIZI BURUK PADA BALITA DI BERBAGAI KABUPATEN/KOTA DI PULAU JAWA DAN BALI
}

\author{
(Relationship between Severe Underweight, GDRP per Capita and Poverty Level and Estimation \\ of Economic Lost of Severe Protein Energy Malnutrition (PEM) among Under-Five Years Old \\ Children in Various Districs/Cities at Java and Bali Islands) \\ Narita Kusumawardhani ${ }^{1}$ dan Drajat Martianto ${ }^{1 *}$ \\ 1 Departemen Gizi Masyarakat, Fakultas Ekologi Manusia, Institut Pertanian Bogor, Bogor 16680. \\ * Alamat korespondensi: Departemen Gizi Masyarakat, Fakultas Ekologi Manusia, Institut Pertanian \\ Bogor, Bogor 16680. Telp: 0251-8621258; Fax: 0251-8622276; Email: drajat_martianto@yahoo.com
}

\begin{abstract}
Malnutrition may decrease in human resources work capacity which is lead to regional economic lost. The study was aimed to find the relationship between severe underweight, GDRP and poverty level and to estimate economic lost due to severe Protein Energy Malnutrition (PEM) among underfive children in various districs/cities at Java and Bali Islands. A descriptive study designed was implemented and a set of secondary data was used in the study. The data uses are prevalence of PEM among underfive children from 2007 Riskesdas, Gross Domestic Regional Product (GDRP), population by sex and age group, and poverty level. Data processing and analysis were conducted in Bogor, from April to July 2010. The result showed that economic lost due to PEM was highest in Bekasi Regency, West Java and lowest in Kepulauan Seribu Regency, DKI Jakarta. Higher GDRP per capita means lower severe PEM prevalence and higher poverty level means higher severe PEM prevalence. Percentage of total economic lost due to severe PEM among under five children was ranged from 0,039\% GDRP - 0,177\% GDRP.
\end{abstract}

Key words: economic Lost, Protein Energy Malnutrition, Java and Bali Islands.

\section{PENDAHULUAN}

Masalah gizi makro, terutama masalah Kurang Energi Protein (KEP) telah mendominasi perhatian para pakar gizi selama puluhan tahun. Anak balita merupakan golongan penduduk yang rawan terhadap kekurangan gizi termasuk KEP (Syarief 2004). Kejadian kurang gizi pada balita terjadi di berbagai wilayah Indonesia termasuk di kabupaten/kota di Pulau Jawa dan Bali yang relatif lebih maju dari sisi keadaan sosial ekonomi dan infrastruktur dibandingkan dengan wilayah lain di Indonesia. KEP yang memiliki spektrum dari ringan, sedang hingga berat (biasa disebut gizi buruk) berdampak pada terjadinya kematian anak, penyakit anak, gangguan pertumbuhan fisik, penurunan kemampuan belajar, penurunan kemampuan kognitif, anggaran pencegahan dan perawatan yang meningkat sampai pada penurunan produktivitas kerja yang pada akhirnya berdampak pada timbulnya kerugian ekonomi pada wilayah tersebut (Aries, 2006).

Gizi yang baik merupakan dasar yang membangun sumber daya manusia dan akan berkontribusi dalam pembangunan ekonomi.
Oleh karena itu, perbaikan gizi merupakan suatu investasi yang sangat menguntungkan. Setidaknya ada tiga alasan suatu negara perlu melakukan intervensi di bidang gizi. Pertama, perbaikan gizi memiliki keuntungan ekonomi (economic returns) yang tinggi; kedua, intervensi gizi terbukti mendorong pertumbuhan ekonomi; dan ketiga, perbaikan gizi membantu menurunkan tingkat kemiskinan melalui perbaikan produktivitas kerja, pengurangan hari sakit, dan pengurangan biaya pengobatan (World Bank, 2006).

Selama ini kajian mengenai masalah gizi buruk lebih banyak diarahkan dari sudut pandang kesehatan dan belum banyak diarahkan dari kerugian ekonomi yang ditimbulkannya, padahal masalah gizi buruk berpotensi menimbulkan kerugian ekonomi melalui penurunan produktivitas kerja penderitanya. Pulau Jawa dan Bali merupakan wilayah di Indonesia yang relatif maju secara sosial dan ekonomi, namun di sisi lain masih memiliki masalah gizi buruk serta variasi yang cukup tajam dalam hal potensi ekonomi (PDRB) serta tingkat kemiskinan antar kabupaten/kota. 
Penelitian ini bertujuan untuk menganalisis hubungan antara tingkat kemiskinan dan PDRB/kapita dengan prevalensi gizi buruk di berbagai kabupaten/kota di Pulau Jawa dan Bali dan untuk mengestimasi kerugian ekonomi akibat gizi buruk pada balita yang terjadi di berbagai wilayah kabupaten/kota di Pulau Jawa dan Bali.

\section{METODE PENELITIAN}

\section{Desain, Tempat, dan Waktu Penelitian}

Penelitian ini merupakan penelitian yang bersifat deskriptif. Penelitian ini dilakukan dengan mengolah data sekunder yang diperoleh dari berbagai instansi terkait. Penelitian mengambil contoh 124 kabupaten/kota di Pulau Jawa dan Bali. Pengolahan data dilaksanakan di Bogor, Jawa Barat pada bulan AprilJuli 2010.

\section{Jenis dan Cara Pengumpulan Data}

Data yang digunakan dalam penelitian ini adalah data sekunder yang secara rinci dapat dilihat pada Tabel 1.

\section{Pengolahan dan Analisis Data}

Data yang telah diperoleh kemudian diolah dengan menggunakan program Microsoft Excel 2007 for Windows. Selain itu dilakukan analisis biplot dengan menggunakan software SAS 9.2 untuk melihat hubungan antara tingkat pendapatan daerah (PDRB/kapita) dan tingkat kemiskinan dengan prevalensi gizi buruk. Tahapan-tahapan serta rumus perhitungan yang digunakan untuk menghitung besarnya potensi ekonomi yang hilang akibat KEP pada balita berdasarkan tahapan dan rumus yang dikemukakan oleh Konig (1995) dalam Jalal dan Atmojo (1998). Untuk mengetahui besarnya nilai ekonomi atau produktivitas potensial dari setiap anak pada saat anak mulai bekerja digunakan rumus berikut :

$$
\mathrm{FV}_{[r, \mathrm{t}]}=\mathrm{P}_{0}(1+\mathrm{r})^{\mathrm{t}}
$$

Keterangan :

$\mathrm{FV}_{[r, t]}=$ Nilai ekonomi anak pada saat anak mulai bekerja (usia 15 tahun)

$\mathrm{P}_{0} \quad=$ Besarnya PDRB saat anak lahir (usia 0 tahun)

$r=$ Discount rate $(5 \%)$

$\mathrm{t}=$ Umur saat mulai bekerja (15 tahun)

Nilai ekonomi sampai anak tersebut memasuki masa pensiun dihitung dengan menggunakan rumus berikut.

$$
F A_{[r, t]}=\frac{F V_{[r, t]}\left[(1+r)^{t}-1\right]}{r}
$$

Keterangan :

$\mathrm{FVA}_{[r, \mathrm{t}]}=$ Total pendapatan sampai pensiun

$\mathrm{FV}_{[r, t]}=$ Besarnya pendapatan saat mulai bekerja

$r=$ Discount rate $(5 \%)$

$\mathrm{t}=$ Periode lama bekerja ( 55 tahun -15 tahun $=40$ tahun)

Besarnya potensi yang dimiliki oleh anak pada saat anak berusia 0 tahun dihitung dengan menggunakan rumus berikut :

$$
P V_{[0]}=\frac{F V A_{[r, t]}}{(1+r)^{t}}
$$

Keterangan :

$\mathrm{PV}_{[0]}=$ Potensi ekonomi anak saat berumur 0 tahun

$\mathrm{FVA}_{[,, t]}=$ Total pendapatan sampai pensiun

$r=$ Discount rate $(5 \%)$

$\mathrm{t}=$ Periode lama bekerja (55 tahun -15 tahun $=40$ tahun)

Berdasarkan rumus perhitungan di atas diketahui bahwa bayi yang lahir di Indonesia pada tahun tertentu akan mempunyai produktivitas potensial sebesar $\mathrm{PV}_{[0]}$ dan besarnya potensi ekonomi yang hilang karena ada anak- anak atau balita yang menderita gizi buruk dihitung dengan menggunakan rumus:

Potensi ekonomi yang hilang $=\operatorname{Prev} \times \Sigma B L \times P V_{[0]}$

Keterangan :

Prev $=$ Prevalensi balita yang mengalami KEP di suatu wilayah

$\Sigma B L=$ Jumlah bayi yang lahir hidup di suatu wilayah di tahun tertentu

$\mathrm{PV}_{[0]}=$ Potensi yang dimiliki oleh anak saat berusia 0 tahun

Tabel 1. Jenis data yang digunakan, tahun, dan sumber data penelitian

\begin{tabular}{clcc}
\hline No & \multicolumn{1}{c}{ Nama Data } & Tahun & \multicolumn{1}{c}{ Sumber } \\
\hline 1 & $\begin{array}{l}\text { Prevalensi status gizi pada balita di berbagai kabupaten/kota } \\
\text { di Pulau Jawa dan Bali }\end{array}$ & 2007 & Riskesdas, Depkes RI \\
2 & $\begin{array}{l}\text { Produk Domestik Regional Bruto (PDRB) per kapita masing- } \\
\text { masing kabupaten/kota di Pulau Jawa dan Bali atas dasar } \\
\text { harga berlaku tanpa migas }\end{array}$ & 2007 & BPS RI \\
3 & $\begin{array}{l}\text { Data penduduk menurut jenis kelamin dan kelompok umur } \\
\text { pada masing-masing kabupaten/kota di Pulau Jawa dan Bali } \\
\text { Data prevalensi kemiskinan kabupaten/kota di Pulau Jawa } \\
\text { dan Bali }\end{array}$ & 2007 & BPS RI \\
\hline
\end{tabular}


Besarnya nilai potensi ekonomi yang hilang berdasarkan rumus perhitungan Konig (1995) berlaku jika anak-anak atau balita yang menderita gizi buruk tersebut sudah $100 \%$ tidak produktif. Pada kondisi yang sebenarnya, anak-anak atau balita tersebut masih dapat pulih sehingga tetap masih mempunyai produktivitas yang besarnya kurang dari 100\%. Berdasarkan penelitian yang dilakukan oleh Ross dan Horton (1998) dalam Horton (1999) diketahui bahwa pada anak-anak yang mempunyai riwayat gizi buruk (z-skor < -3.0 dengan indikator $\mathrm{BB} / \mathrm{U})$ maka akan mengalami kehilangan produktivitas $2 \%$ - 9\%. Seseorang yang pada saat anak-anak mempunyai riwayat gizi buruk akan kehilangan produkivitas yang besarnya adalah seperti berikut:

Potensi ekonomi yang hilang $=$
$f$ cor $\times$ Prev $\times \Sigma B L \times \mathrm{PV}_{[0]}$

Keterangan :

f cor $=$ Faktor koreksi $(2 \%-9 \%)$

Prev $=$ Prevalensi balita yang mengalami KEP di suatu wilayah

$\Sigma B L=$ Jumlah bayi yang lahir hidup di suatu wilayah di tahun tertentu

$\mathrm{PV}_{[0]}=$ Potensi yang dimiliki oleh anak saat berusia 0 tahun

\section{Asumsi dan Keterbatasan Penelitian}

Penelitian ini menggunakan beberapa asumsi dan mempunyai beberapa keterbatasan. Asumsi-asumsi tersebut digunakan agar hasil penelitian dapat diterima secara umum. Asumsi-asumsi yang digunakan dalam penelitian ini adalah sebagai berikut: (1) Keadaan wilayah yang diteliti stabil dan normal, yaitu tidak ada kejadian khusus yang menyebabkan terjadinya perubahan sosial dan ekonomi secara drastis seperti bencana alam, wabah, dan konflik atau investasi ekonomi secara masif; (2) Individu yang mengalami gizi buruk akan mengalami kehilangan produktivitas 2\% - 9\% berdasarkan hasil penelitian oleh Ross dan Horton tahun 1998.

\section{HASIL DAN PEMBAHASAN}

\section{Prevalensi Gizi Buruk di Pulau Jawa dan Bali}

Berdasarkan hasil pengolahan data RISKESDAS tahun 2007, diketahui bahwa besarnya prevalensi gizi buruk (z-skor < -3.0) pada balita dengan indikator berat badan menurut umur (BB/U) di wilayah Pulau Jawa dan Bali adalah sebesar $4.0 \%$. Hasil pengolahan data RISKESDAS tahun 2007 tersebut menunjukkan bahwa di wilayah Pulau Jawa dan Bali terdapat 454.461 balita yang mengalami gizi buruk dari total 11.270.033 balita yang terdapat di wilayah Pulau Jawa dan Bali. Prevalensi balita gizi buruk yang tertinggi terdapat di Kabupaten Sampang, Provinsi Jawa Timur yaitu sebesar $16.2 \%$ sedangkan prevalensi gizi buruk yang terendah terdapat di Kota Madiun, Provinsi Jawa Timur yaitu sebesar $1.0 \%$. Kabupaten/kota di wilayah Pulau Jawa dan Bali dengan prevalensi gizi buruk tertinggi pada tahun 2007 secara lebih rinci dapat dilihat pada Tabel 2.

Berdasarkan data pada Tabel 2 dapat diketahui bahwa status Kabupaten Sumenep, Pamekasan, Probolinggo, Klaten, dan Demak adalah tinggi sedangkan status Kabupaten Pasuruan, Rembang, dan Karang Asem adalah sedang. Walaupun status kabupaten-kabupaten tersebut belum termasuk dalam kategori sangat tinggi, tetapi prevalensi gizi buruk pada kabupaten-kabupaten tersebut termasuk dalam sepuluh kabupaten/kota yang memiliki prevalensi gizi buruk tertinggi di Pulau Jawa dan Bali. Untuk mengetahui prevalensi kabupaten/kota dengan status prevalensi gizi buruk

Tabel 2. Sepuluh Kabupaten/Kota di Pulau Jawa dan Bali dengan Prevalensi Gizi Buruk Tertinggi Tahun 2007

\begin{tabular}{clcccc}
\hline No & \multicolumn{1}{c}{ Kabupaten/Kota } & $\begin{array}{c}\text { Gizi Buruk } \\
(\%)\end{array}$ & $\begin{array}{c}\text { Gizi Kurang } \\
(\%)\end{array}$ & $\begin{array}{c}\text { Gizi Buruk + } \\
\text { Gizi Kurang (\%) }\end{array}$ & $\begin{array}{c}\text { Status Prevelensi KEP } \\
\text { Kabupaten/Kota }\end{array}$ \\
\hline 1 & Kab Sampang & 16.2 & 15.0 & 31.2 & sangat tinggi \\
2 & Kab Jember & 9.3 & 21.1 & 30.4 & sangat tinggi \\
3 & Kab Sumenep & 8.5 & 20.9 & 29.4 & tinggi \\
4 & Kab Pamekasan & 8.5 & 18.5 & 27.0 & tinggi \\
5 & Kab Probolinggo & 8.3 & 16.3 & 24.6 & tinggi \\
6 & Kab Pasuruan & 8.0 & 11.3 & 19.3 & sedang \\
7 & Kab Rembang & 8.0 & 10.5 & 21.3 & sedang \\
8 & Kab Klaten & 7.8 & 13.5 & 19.8 & tinggi \\
9 & Kab Karang Asem & 7.8 & 12.0 & 21.5 & sedang \\
10 & Kab Demak & 7.7 & 13.8 & & tinggi \\
\hline
\end{tabular}

Sumber: RISKESDAS 2007 (diolah)

Keterangan:

Cut off point pengelompokan masalah kesehatan masyarakat berdasarkan prevalensi gizi buruk dan gizi kurang menurut WHO (1999) adalah: Rendah < 10\%; Sedang = 10-19.9\%; Tinggi = 20-29.9\%; Sangat tinggi $\geq 30 \%$ 

dan gizi kurang yang termasuk dalam kategori tinggi dan sangat tinggi di Pulau Jawa dan Bali dapat dilihat pada Tabel 3.

Tabel 3. Prevalensi Kabupaten/Kota dengan Status Prevalensi Gizi Buruk dan Gizi Kurang dalam Kategori Tinggi dan Sangat Tinggi di Pulau Jawa dan Bali

\begin{tabular}{lcc}
\hline Provinsi & $\begin{array}{c}\sum \text { Kabupaten/ } \\
\text { kota }\end{array}$ & $\begin{array}{c}\text { \% Terhadap } \\
\text { wilayah kab/kota } \\
\text { di prov }\end{array}$ \\
\hline DKI Jakarta & 1 & 16.7 \\
Jawa Barat & 1 & 4.0 \\
Jawa Tengah & 8 & 22.9 \\
DI Yogyakarta & 0 & 0.0 \\
Jawa Timur & 7 & 18.4 \\
Banten & 2 & 33.3 \\
Bali & 0 & 0.0 \\
\hline
\end{tabular}

Berdasarkan Tabel 3 dapat diketahui bahwa provinsi yang memiliki prevalensi kabupaten/kota dengan jumlah status gizi buruk dan gizi kurang dalam kategori tinggi dan sangat tinggi yang terbesar adalah di Provinsi Banten yaitu sebesar $33.3 \%$ sementara yang terendah adalah di Provinsi DI Yogyakarta dan Provinsi Bali yaitu 0.0\%.

Menurut hasil Riskesdas tahun 2007, secara umum prevalensi gizi buruk di Indonesia adalah $5.4 \%$ dan gizi kurang $13.0 \%$. Untuk wilayah Pulau Jawa dan Bali, prevalensi gizi buruknya adalah sebesar $4.0 \%$ dan prevalensi gizi kurang adalah $11.6 \%$, kedua nilai tersebut sudah berada di bawah prevalensi nasional di Indonesia. Target pencapaian program perbaikan gizi pada Rencana Pembangunan Jangka Menengah Nasional (RPJMN) tahun 2004-2009 sebesar $20 \%$ dan target Millenium Development Goals pada tahun 2015 untuk Indonesia sebesar $18.5 \%$, maka secara nasional pada tahun 2007 target-target tersebut sudah terlampaui. Namun pencapaian tersebut belum merata di 33 provinsi. Untuk mengetahui kabupaten/kota yang telah memenuhi target RPJMN dan Millenium Development Goals secara lebih rinci dapat dilihat pada Tabel 4.

Tabel 4. Prevalensi Kabupaten/Kota yang Telah Memenuhi Target RPJMN dan MDGs menurut Provinsi di Wilayah Pulau Jawa dan Bali

\begin{tabular}{lcccc}
\hline \multirow{2}{*}{ Provinsi } & \multicolumn{2}{c}{$\begin{array}{c}\text { Kabupaten/ } \\
\text { kota }\end{array}$} & $\begin{array}{c}\text { \% Terhadap wilayah } \\
\text { kab/kota di prov }\end{array}$ \\
\cline { 2 - 5 } & RPJMN & MDGs & RPJMN & MDGs \\
\hline DKI Jakarta & 5 & 5 & 83.3 & 83.3 \\
Jawa Barat & 24 & 21 & 96.0 & 84.0 \\
Jawa Tengah & 27 & 27 & 77.1 & 77.1 \\
DI Yogyakarta & 5 & 5 & 100.0 & 100.0 \\
Jawa Timur & 31 & 26 & 81.6 & 68.4 \\
Banten & 4 & 4 & 66.7 & 66.7 \\
Bali & 9 & 8 & 100.0 & 88.9 \\
\hline
\end{tabular}

Berdasarkan Tabel 4 dapat diketahui bahwa terdapat 2 provinsi yang seluruh kabupaten/kotanya telah memenuhi target pencapaian program perbaikan gizi RPJMN tahun 2009 sebesar 20\% yaitu di Provinsi DI Yogyakarta dan Provinsi Bali. Seluruh kabupaten/ kota di Provinsi DI Yogyakarta juga telah memenuhi target MDGs. Sementara itu, provinsi dengan prevalensi kabupaten/kota yang telah memenuhi target RPJMN dan MDGs terendah adalah Provinsi Banten yaitu baru sekitar 66.7\% dari total jumlah kabupaten/kota di Provinsi Banten.

Hubungan PDRB Per Kapita dan Tingkat Kemiskinan dengan Prevalensi Gizi Buruk pada Balita di Berbagai Kabupaten/Kota di Pulau Jawa dan Bali

Produk Domestik Regional Bruto (PDRB) adalah total nilai produksi barang dan jasa yang diproduksi di wilayah (regional) tertentu dalam waktu tertentu (1 tahun). PDRB per kapita diperoleh apabila PDRB dibagi dengan jumlah penduduk pertengahan tahun yang tinggal di wilayah tertentu (BPS 2008). PDRB yang digunakan dalam penelitian ini adalah PDRB per kapita atas dasar harga berlaku tanpa minyak bumi dan gas (migas) menurut kabupaten/kota tahun 2007. Nilai PDRB yang besar menunjukkan kemampuan sumber daya ekonomi yang besar begitu pun sebaliknya. Kabupaten/kota di wilayah Pulau Jawa dan Bali dengan nilai PDRB per kapita atas dasar harga berlaku tanpa minyak bumi dan gas (migas) yang tertinggi tahun 2007 dapat dilihat pada Tabel 5.

Berdasarkan Tabel 5 dapat diketahui bahwa sepuluh kabupaten/kota dengan nilai PDRB per kapita atas dasar harga berlaku tanpa migas yang tertinggi pada tahun 2007 seluruhnya berada di Pulau Jawa. Untuk mengetahui hubungan antara prevalensi gizi buruk (\%) dengan PDRB per kapita pada berbagai wilayah kabupaten/kota di Pulau Jawa dan Bali dapat dilihat pada Gambar 1.

Berdasarkan Gambar 1 dapat diketahui bahwa persamaan garis yang diperoleh adalah $y=4.286-3.10^{-8} x$ sehingga dapat disimpulkan terdapat hubungan negatif antara PDRB per kapita dengan prevalensi gizi buruk (ditandai dengan nilai slope yang negatif). Hal tersebut memiliki arti semakin tinggi nilai PDRB per kapita di suatu wilayah maka akan semakin rendah prevalensi gizi buruk di wilayah tersebut begitu pun sebaliknya. 

Tabel 5. Sepuluh Kabupaten/Kota di Pulau Jawa dan Bali dengan Nilai PDRB per Kapita Tertinggi Tahun 2007*

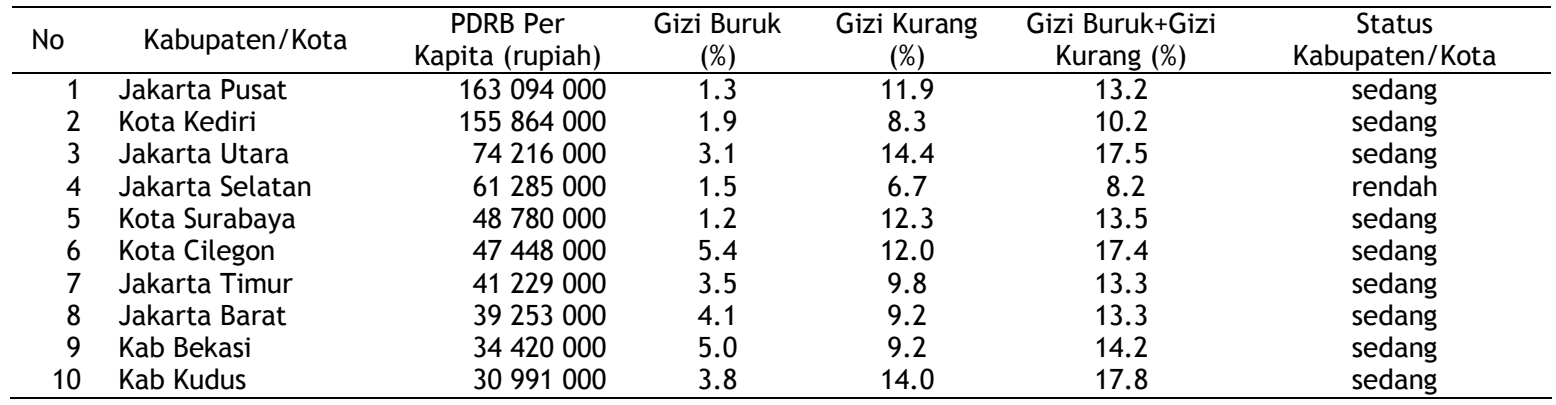

* Atas dasar harga berlaku tanpa migas

Sumber: BPS 2009 dan RISKESDAS 2007 (diolah)

Keterangan:

Cut off point pengelompokan masalah kesehatan masyarakat berdasarkan prevalensi gizi buruk dan gizi kurang menurut WHO (1999) adalah: Rendah < 10\%; Sedang = 10-19.9\%; Tinggi = 20-29.9\%; Sangat tinggi $\geq 30 \%$

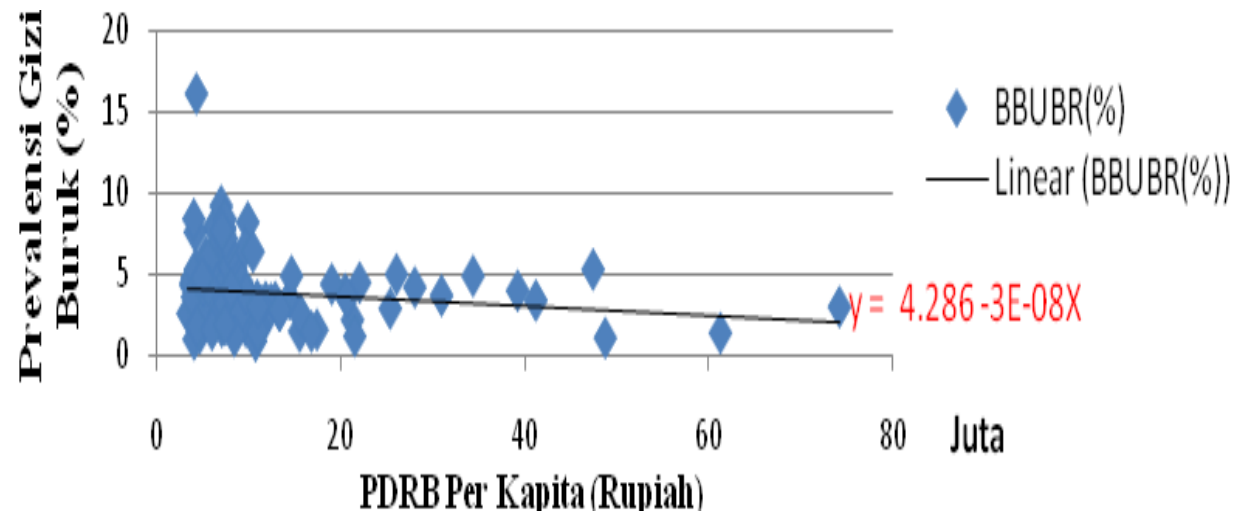

Gambar 1. Hubungan antara Prevalensi Gizi Buruk (\%) dengan PDRB per Kapita di Berbagai Kabupaten/Kota di Pulau Jawa dan Bali

Hal lain yang memiliki hubungan dengan prevalensi gizi buruk dan gizi kurang adalah tingkat kemiskinan. Konsep kemiskinan yang digunakan dalam penelitian ini adalah konsep kemiskinan menurut Badan Pusat Statistik (BPS). Untuk mengukur kemiskinan, BPS menggunakan konsep kemampuan memenuhi kebutuhan dasar (basic needs approach). Dengan pendekatan ini, kemiskinan dipandang sebagai ketidakmampuan dari sisi ekonomi untuk memenuhi kebutuhan dasar makanan dan bukan makanan yang diukur dari sisi pengeluaran (BPS, 2008). Kabupaten/kota di wilayah Pulau Jawa dan Bali dengan tingkat kemiskinan yang tertinggi pada tahun 2007 dapat dilihat pada Tabel 6.

Berdasarkan Tabel 6 dapat diketahui bahwa sepuluh kabupaten dengan tingkat kemiskinan tertinggi tahun 2007 seluruhnya berada di Pulau Jawa yaitu terletak di wilayah Provinsi Jawa Timur, Jawa Tengah, dan DI Yogyakarta. Status kabupaten/kota berdasarkan prevalensi gizi buruk dan gizi kurang pada sepuluh wilayah tersebut sebagian besar ter- masuk dalam kategori sedang. Untuk melihat hubungan antara tingkat kemiskinan dengan prevalensi gizi buruk pada berbagai wilayah kabupaten/kota di Pulau Jawa dan Bali dapat dilihat pada Gambar 2.

Berdasarkan Gambar 2, dapat diketahui bahwa persamaan garis yang diperoleh adalah $y=2.174+0.106 x$ sehingga dapat disimpulkan terdapat hubungan positif antara tingkat kemiskinan dengan prevalensi gizi buruk (ditandai dengan nilai slope yang positif). Hal tersebut memiliki arti semakin tinggi tingkat kemiskinan di suatu wilayah maka akan semakin tinggi prevalensi gizi buruk di wilayah tersebut, begitupula sebaliknya.

Selain itu, dilakukan analisis biplot untuk melihat hubungan antara tingkat pendapatan daerah (PDRB/kapita) dan tingkat kemiskinan dengan prevalensi gizi buruk (KEP). Hubungan antara tingkat pendapatan daerah (PDRB/kapita) dan tingkat kemiskinan dengan prevalensi gizi buruk (KEP) dapat dilihat secara lebih rinci pada Gambar 3. 

Tabel 6. Sepuluh Kabupaten/Kota di Pulau Jawa dan Bali dengan Tingkat Kemiskinan yang Tertinggi Tahun 2007

\begin{tabular}{|c|c|c|c|c|c|c|c|}
\hline No & Kab/Kota & $\begin{array}{c}\text { Tingkat } \\
\text { Kemiskinan } \\
(\%)\end{array}$ & $\begin{array}{c}\text { Status Kab/Kota } \\
\text { (berdasarkan } \\
\text { tingkat } \\
\text { kemiskinan) }\end{array}$ & $\begin{array}{l}\text { Gizi } \\
\text { Buruk } \\
(\%)\end{array}$ & $\begin{array}{c}\text { Gizi } \\
\text { Kurang } \\
\text { (\%) }\end{array}$ & $\begin{array}{c}\text { Gizi Buruk } \\
+ \text { Kurang } \\
\text { (\%) }\end{array}$ & $\begin{array}{c}\text { Status Kab/Kota } \\
\text { (berdasarkan } \\
\text { prevalensi gizi } \\
\text { buruk+kurang) }\end{array}$ \\
\hline 1 & Kab Sampang & 39.4 & tinggi & 16.2 & 15.0 & 31.2 & sangat tinggi \\
\hline 2 & Kab Sumenep & 33.0 & tinggi & 8.5 & 20.9 & 29.4 & tinggi \\
\hline 3 & Kab Pamekasan & 32.4 & tinggi & 8.5 & 18.5 & 27.0 & tinggi \\
\hline 4 & Kab Wonosobo & 32.3 & tinggi & 4.9 & 10.2 & 15.1 & sedang \\
\hline 5 & Kab Bangkalan & 31.6 & tinggi & 6.0 & 18.4 & 24.4 & tinggi \\
\hline 6 & Kab Rembang & 30.7 & tinggi & 8.0 & 10.5 & 18.5 & sedang \\
\hline 7 & Kab Kebumen & 30.3 & tinggi & 4.4 & 9.7 & 14.1 & sedang \\
\hline 8 & Kab Purbalingga & 30.2 & tinggi & 1.5 & 11.4 & 12.9 & sedang \\
\hline 9 & Kab Gunung Kidul & 28.9 & tinggi & 1.9 & 11.5 & 13.4 & sedang \\
\hline 10 & Kab Kulon Progo & 28.6 & tinggi & 2.3 & 12.3 & 14.6 & sedang \\
\hline
\end{tabular}

Sumber: BPS 2007 dan RISKESDAS 2007 (diolah)

Keterangan:

Cut off point pengelompokan wilayah berdasarkan prevalensi kemiskinan (Rendah < 10\%; Sedang = 10-20\%; Tinggi >20\%). Cut off point pengelompokan masalah kesehatan masyarakat berdasarkan prevalensi gizi buruk dan gizi kurang menurut WHO (1999) (Rendah < 10\%; Sedang = 10-19.9\%; Tinggi = 20-29.9\%; Sangat tinggi $\geq 30 \%$ ).

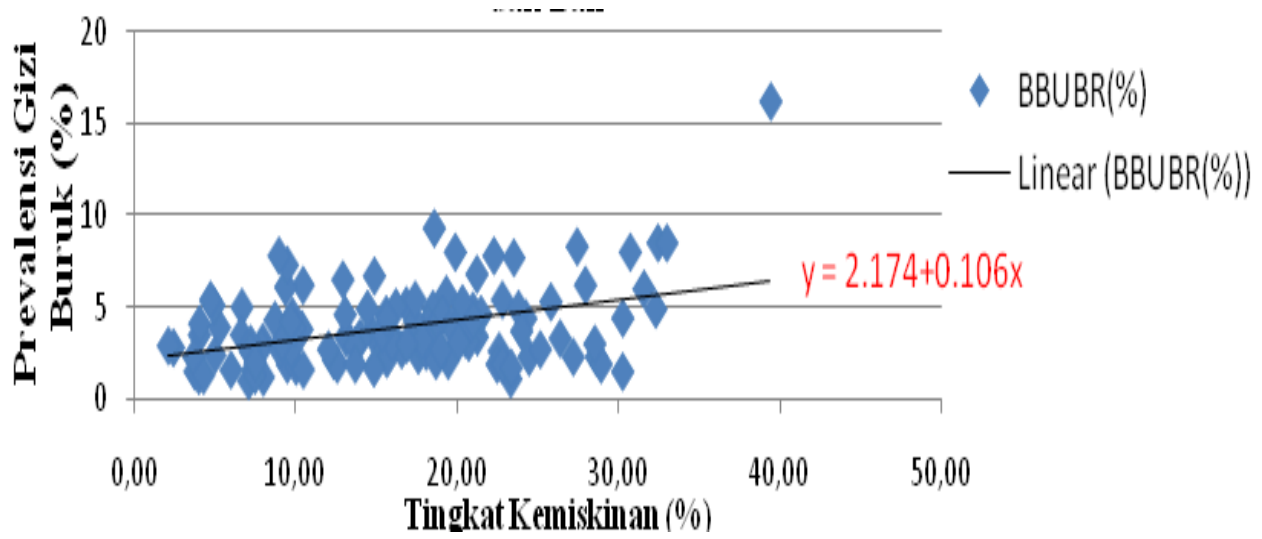

Gambar 2. Hubungan antara Prevalensi Gizi Buruk (\%) dengan Tingkat Kemiskinan (\%) di Berbagai Kabupaten/Kota di Pulau Jawa dan Bali

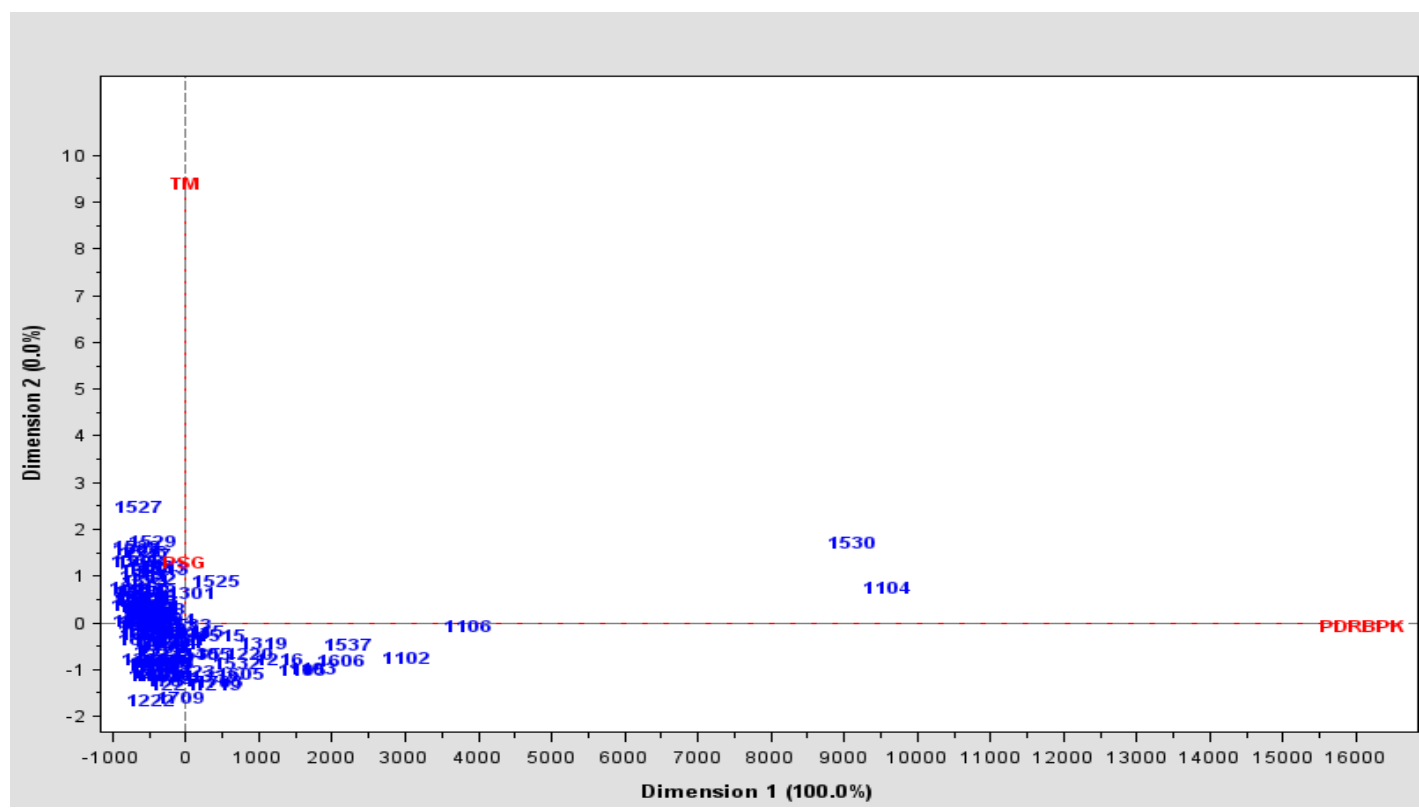

Gambar 3. Analisis Biplot Hubungan antara Tingkat Pendapatan Daerah (PDRB/kapita) dan Tingkat Kemiskinan dengan Prevalensi Gizi Buruk (KEP) pada Kabupaten/Kota di Pulau Jawa dan Bali 

Vektor PDRB per kapita (PDRBPK) adalah vektor yang paling panjang sehingga menunjukkan bahwa data PDRBPK di Pulau Jawa dan Bali sangat beragam. Untuk vektor TM memiliki keragaman yang lebih besar dibandingkan PSGB. Keberhimpitan vektor TM dan PSGB memiliki hubungan korelasi positif yang kuat. Artinya semakin tinggi TM maka PSGB akan semakin tinggi pula. Kota Kediri dan Jakarta Pusat memiliki nilai PDRBPK yang jauh lebih tinggi dibanding objek yang lainnya. Sementara itu, Kabupaten Sampang memiliki nilai PSGB dan TM yang terbesar dibanding daerah lainnya. Secara garis besar semua daerah dikelompokkan ke dalam 4 kelompok yaitu kuadran I, II, III, dan IV.

Sebagian besar data terpusat atau berkumpul pada kuadran II yaitu dari total 124 kabupaten/kota di Pulau Jawa dan Bali sebanyak 56 kabupaten/kota terletak di kuadran II. Kuadran II memiliki karakteristik nilai PDRB per kapita rendah sementara prevalensi status gizi buruk dan tingkat kemiskinan cenderung tinggi. Hal tersebut sesuai dengan pernyataan Soekirman (2005) bahwa proporsi anak yang mengalami gizi kurang dan gizi buruk berbanding terbalik dengan pendapatan. Semakin kecil pendapatan penduduk maka semakin tinggi persentase anak yang mengalami kekurangan gizi.

Kuadran III memiliki karakteristik nilai PDRB per kapita yang rendah serta prevalensi status gizi buruk dan tingkat kemiskinan juga tergolong rendah. Hal tersebut menunjukkan bahwa kabupaten/kota yang terletak di kuadran III dapat memanfaatkan potensi yang ada dengan baik. Walaupun PDRB per kapita kabupaten/kota di wilayah tersebut tergolong rendah tetapi prevalensi gizi buruknya juga rendah. Hal ini menunjukkan adanya penyimpangan positif (positive deviance). Menurut Sandjaja (2001), sebagian anak dalam keluarga tertentu dengan status sosial ekonomi rendah mempunyai daya adaptasi yang tinggi sehingga mampu tumbuh dan kembang (penyimpangan positif = positive deviance) terhadap tekanan ekonomi, sosial dan lingkungan. Faktor-faktor positive deviance yang berperan nyata dalam status gizi anak antara lain adalah faktor ibu, pola asuh anak, keadaan kesehatan anak, dan konsumsi makanan anak.

Kuadran IV memiliki kecenderungan nilai PDRB per kapita yang cukup tinggi sedangkan tingkat kemiskinan dan prevalensi gizi buruknya tergolong rendah. Hal tersebut merupakan harapan dari setiap kabupaten/kota dimana pendapatan daerah yang tinggi sementara prevalensi gizi buruk dan tingkat kemiskinan nya rendah sehingga dapat dikatakan bahwa kabupaten/kota yang termasuk ke dalam kuadran IV adalah kabupaten/kota yang sudah cukup baik dalam pemanfaatan potensi yang terdapat di wilayahnya serta penanganan gizi buruk di wilayahnya. Kuadran I memiliki kecenderungan tingkat PDRB per kapita yang cukup tinggi namun tingkat kemiskinan dan prevalensi gizi buruknya cukup tinggi juga. Hal ini menunjukkan bahwa kabupaten/kota yang termasuk ke dalam kuadran I belum dapat memanfaatkan potensi yang ada dengan maksimal. Proporsi pembagian kabupaten/kota di wilayah Pulau Jawa dan Bali ke dalam masingmasing kuadran dapat dilihat pada Tabel 7.

Dengan melihat proporsi pembagian wilayah kabupaten/kota di Pulau Jawa dan Bali ke dalam tiap kuadran tersebut maka dapat disimpulkan bahwa masih banyak kabupaten/ kota yang terdapat di wilayah Pulau Jawa khususnya yang memiliki prevalensi status gizi buruk dan tingkat kemiskinan yang cukup tinggi oleh karena itu perlu dilakukan upaya penanganan dan penanggulangan yang lebih maksimal untuk mengatasi masalah gizi buruk dan kemiskinan di wilayah tersebut.

Tabel 7. Pembagian Kabupaten/Kota di Wilayah Pulau Jawa dan Bali ke Dalam Tiap Kuadran

\begin{tabular}{lcccccccc}
\hline & \multicolumn{2}{c}{ Kuadran I } & \multicolumn{2}{c}{ Kuadran II } & \multicolumn{2}{c}{ Kuadran III } & \multicolumn{2}{c}{ Kuadran IV } \\
\cline { 2 - 8 } \multicolumn{1}{c}{ Provinsi } & $\begin{array}{c}\Sigma \\
\text { Kab/ } \\
\text { kota }\end{array}$ & $\begin{array}{c}\text { \% Thdp } \\
\text { kab/kot } \\
\text { di prov }\end{array}$ & $\begin{array}{c}\Sigma \\
\text { Kab/ } \\
\text { kota }\end{array}$ & $\begin{array}{c}\% \text { Thdp } \\
\text { kab/kot } \\
\text { di prov }\end{array}$ & $\begin{array}{c}\sum \\
\text { Kab/ } \\
\text { kota }\end{array}$ & $\begin{array}{c}\text { \% Thdp } \\
\text { kab/kot } \\
\text { di prov }\end{array}$ & $\begin{array}{c}\Sigma \\
\text { Kab/ } \\
\text { kota }\end{array}$ & $\begin{array}{c}\text { Thdp } \\
\text { kab/kota di } \\
\text { prov }\end{array}$ \\
\hline DKI Jakarta & 1 & 16.7 & 0 & 0.0 & 1 & 16.7 & 4 & 66.7 \\
Jawa Barat & 0 & 0.0 & 8 & 32.0 & 11 & 44.0 & 6 & 24.0 \\
Jawa Tengah & 1 & 2.9 & 23 & 65.7 & 9 & 25.7 & 2 & 5.7 \\
DI Yogyakarta & 0 & 0.0 & 3 & 60.0 & 1 & 20.0 & 1 & 20.0 \\
Jawa Timur & 3 & 7.9 & 22 & 57.9 & 9 & 23.7 & 4 & 10.5 \\
Banten & 0 & 0.0 & 0 & 0.0 & 4 & 66.7 & 2 & 33.3 \\
Bali & 0 & 0.0 & 0 & 0.0 & 8 & 88.9 & 1 & 11.1 \\
\hline
\end{tabular}





\section{Estimasi Potensi Ekonomi yang Hilang Akibat Gizi Buruk}

Berdasarkan hasil perhitungan dengan menggunakan asumsi penurunan produktivitas sebesar 2\% - 9\% diketahui bahwa wilayah yang mengalami kehilangan potensi ekonomi tertinggi adalah Kabupaten Bekasi, Jawa Barat yaitu sebesar 52.96 miliar rupiah - 238.32 miliar rupiah, sementara yang terendah adalah Kabupaten Administrasi Kepulauan Seribu, DKI Jakarta yaitu 0.12 miliar rupiah - 0.54 miliar rupiah. Kabupaten/kota di wilayah Pulau Jawa dan Bali dengan estimasi potensi ekonomi yang hilang akibat KEP pada balita (asumsi penurunan produktivitas $2 \%$ - 9\%) yang tertinggi pada tahun 2007 secara lebih rinci dapat dilihat pada Tabel 8.

Untuk mengetahui wilayah kabupaten/ kota dengan persentase nilai potensi ekonomi yang hilang terhadap PDRB akibat gizi buruk pada balita dengan asumsi penurunan produktivitas 2\% - 9\% yang tertinggi di Pulau Jawa dan Bali dapat dilihat pada Tabel 9.
Berdasarkan Tabel 9, dapat dilihat bahwa wilayah kabupaten/kota dengan persentase nilai potensi ekonomi yang hilang terhadap PDRB akibat gizi buruk pada balita yang tertinggi adalah di Kabupaten Sampang, Jawa Timur. Sementara itu yang terendah adalah di Kabupaten Pacitan, Jawa Timur yaitu pada asumsi penurunan produktivitas $2 \%$ - $9 \%$ sebesar $0.01 \%-0.04 \%$ PDRB.

Total potensi ekonomi yang hilang akibat gizi buruk pada balita jika saat dewasa mengalami kehilangan produktivitas sebesar 2\% - 9\% di wilayah Pulau Jawa dan Bali adalah sebesar 760.12 miliar rupiah - 3.420.54 miliar rupiah atau 3.4 triliun rupiah. Besarnya ratarata potensi ekonomi yang hilang akibat gizi buruk pada balita jika saat dewasa mengalami kehilangan produktivitas sebesar 2\% - 9\% di wilayah Pulau Jawa dan Bali adalah 6.13 miliar rupiah - 27.59 miliar rupiah. Estimasi potensi ekonomi yang hilang akibat gizi buruk di Pulau Jawa dan Bali berkisar antara 0.039\% - 0.177\% PDRB.

Tabel 8. Sepuluh Kabupaten/Kota dengan Estimasi Kehilangan Potensi Ekonomi Tertinggi (Asumsi Penurunan Produktivitas 2\% - 9\%) di Pulau Jawa dan Bali Tahun 2007

\begin{tabular}{|c|c|c|c|}
\hline \multirow{2}{*}{ No } & \multirow{2}{*}{ Kabupaten/kota } & \multicolumn{2}{|c|}{ Potensi ekonomi yang hilang (miliar rupiah) } \\
\hline & & $2 \%$ & $9 \%$ \\
\hline 1 & Kab Bekasi & 52.96 & 238.32 \\
\hline 2 & Jakarta Barat & 41.80 & 188.09 \\
\hline 3 & Jakarta Utara & 41.11 & 185.00 \\
\hline 4 & Jakarta Timur & 38.78 & 174.49 \\
\hline 5 & Kab Bogor & 24.19 & 108.87 \\
\hline 6 & Jakarta Selatan & 24.17 & 108.75 \\
\hline 7 & Kota Tangerang & 23.78 & 107.02 \\
\hline 8 & Jakarta Pusat & 19.84 & 89.28 \\
\hline 9 & Kab Jember & 19.33 & 86.96 \\
\hline 10 & Kab Sidoarjo & 18.86 & 84.89 \\
\hline
\end{tabular}

Tabel 9. Kabupaten/Kota dengan Persentase Nilai Potensi Ekonomi yang Hilang terhadap PDRB Akibat Gizi Buruk pada Balita dengan Asumsi Penurunan Produktivitas 2\%-9\% yang Tertinggi di Pulau Jawa dan Bali*

\begin{tabular}{rlrrrr}
\hline \multirow{2}{*}{ No } & \multicolumn{1}{c}{ Provinsi } & \multicolumn{2}{c}{$\begin{array}{c}\text { Potensi ekonomi yang hilang } \\
\text { (miliar rupiah) }\end{array}$} & $\begin{array}{c}\text { Persentase terhadap PDR** } \\
\text { (\%) }\end{array}$ \\
\cline { 3 - 6 } & & $\mathbf{2 \%}$ & $\mathbf{9 \%}$ & $\mathbf{2 \%}$ & $\mathbf{9 \%}$ \\
\hline 1 & Kab Sampang & 7.36 & 33.13 & 0.19 & 0.86 \\
2 & Kab Jember & 19.33 & 86.96 & 0.12 & 0.53 \\
3 & Kab Pamekasan & 3.38 & 15.21 & 0.10 & 0.46 \\
4 & Kab Karang Asem & 2.75 & 12.37 & 0.10 & 0.45 \\
5 & Kab Probolinggo & 9.84 & 44.28 & 0.10 & 0.43 \\
6 & Kab Serang & 12.81 & 57.65 & 0.09 & 0.42 \\
7 & Kota Pasuruan & 1.61 & 7.24 & 0.09 & 0.40 \\
8 & Kab Pasuruan & 9.37 & 42.17 & 0.09 & 0.40 \\
9 & Kab Garut & 14.60 & 65.69 & 0.08 & 0.37 \\
10 & Kab Rembang & 2.95 & 13.29 & 0.08 & 0.37 \\
\hline
\end{tabular}

*PDRB atas dasar harga berlaku tanpa migas 



\section{KESIMPULAN}

Terdapat hubungan negatif antara PDRB per kapita dengan prevalensi gizi buruk dan gizi kurang, semakin tinggi nilai PDRB per kapita di suatu wilayah maka semakin rendah prevalensi gizi buruk di wilayah tersebut. Hubungan positif ditemukan antara tingkat kemiskinan dengan prevalensi gizi buruk dan gizi kurang dimana semakin tinggi tingkat kemiskinan di suatu wilayah maka semakin tinggi prevalensi gizi buruk di wilayah tersebut. Berdasarkan analisis biplot diketahui bahwa sebagian besar data (56 dari 124 kabupaten/kota) terpusat pada kuadran II, yaitu wilayah dengan karakteristik nilai PDRB per kapita rendah dan prevalensi status gizi buruk dan tingkat kemiskinan cenderung tinggi.

Berdasarkan hasil perhitungan diketahui bahwa estimasi total potensi ekonomi yang hilang akibat gizi buruk pada balita dengan asumsi kehilangan produktivitas sebesar $2 \%$ 9\% di wilayah Pulau Jawa dan Bali berkisar antara $0.039 \%-0.177 \%$ terhadap PDRB wilayah Pulau Jawa dan Bali. Wilayah yang mengalami kehilangan potensi ekonomi tertinggi adalah Kabupaten Bekasi, Jawa Barat sementara yang terendah adalah Kabupaten Administrasi Kepulauan Seribu, DKI Jakarta. Wilayah kabupaten/ kota dengan persentase nilai potensi ekonomi yang hilang terhadap PDRB akibat gizi buruk balita yang tertinggi adalah di Kabupaten Sampang, Jawa Timur. Sementara itu yang terendah adalah di Kabupaten Pacitan, Jawa Timur.

Mengingat kajian ini masih menggunakan asumsi-asumsi pada persentase kehilangan produktivitas yang berasal dari studi-studi di luar negeri, maka perlu dilakukan kajian tentang kehilangan produktivitas dari studi-studi di Indonesia. Di samping itu perlu dihitung secara seksama besarnya biaya yang diperlukan untuk upaya pencegahan dan penanggulangan gizi buruk (KEP) baik pada balita maupun pada kelompok umur yang lain secara lebih rinci serta penelitian lain yang mengkaji tentang besarnya penurunan produktivitas pada individu yang mengalami KEP baik pada kelompok anakanak maupun dewasa.

\section{DAFTAR PUSTAKA}

Aries M. 2006. Estimasi kerugian ekonomi akibat gizi buruk dan biaya penanggulangannya melalui program pemberian makanan tambahan (PMT) pada balita di berbagai provinsi di Indonesia. Skripsi Sarjana Departemen Gizi Masyarakat, Fakultas Pertanian, IPB, Bogor.

BPS. 2008. PDRB Kabupaten Bondowoso tahun 2008. Badan Pusat Statistik, Bondowoso.

[Depkes] Departemen Kesehatan. 2008. Riset Kesehatan Dasar (RISKESDAS) 2007. http: //www.litbang.depkes.go.id. [5 Agustus 2010].

Horton S. 1999. Opportunities for investments in nutrition in low-income Asia. http:// www.adb.org [5 Feb 2010].

Jalal F \& Atmojo SM. 1998. Gizi dan kualitas hidup: agenda perumusan program gizi Repelita VII untuk mendukung pengembangan sumber daya manusia yang berkualitas. Dalam Prosiding Widyakarya Nasional Pangan dan Gizi (hlm 221-253), 17-20 Februari 1998. LIPI, Jakarta.

Konig S. 1995. The Cost of Malnutrition. Technical Support Group. F. HoffmannLa Roche Ltd, Switzerland.

Ross JS \& Horton S. 1998. Economic Consequences of Iron Deficiency. Micronutrient Initiative, Ottawa.

Sandjaja. 2001. Penyimpangan positif (positif deviance) status gizi anak balita dan faktor-faktor yang berpengaruh. http:// digilib.itb.ac.id. [7 Agustus 2010].

Soekirman. 2005. Gizi buruk, kemiskinan, dan KKN. http://www.gizi.net/cgi-bin/berita/fullnews. [30 Jul 2010].

Syarief H. 2004. Masalah gizi di Indonesia: kondisi gizi masyarakat memprihatinkan. http://www.gizi.net. [5 Feb 2010].

World Bank. 2006. Repositioning Nutrition as Central to Development: A Strategy for Large-Scale Action. The International Bank for Reconstruction and Development/The World Bank, Washington DC. 